\title{
Developing the Material Guidebook on Parents Gathering to Improve Parents and Teachers' Knowledge of Children Care
}

\author{
Muthmainnah* \\ Early Childhood Education Department \\ Faculty of Educational Science \\ Universitas Negeri Yogyakarta \\ Yogyakarta, Indonesia muthmainnah@uny.ac.id* \\ Rina Wulandari \\ Early Childhood Education Department \\ Faculty of Educational Science \\ Universitas Negeri Yogyakarta \\ Yogyakarta, Indonesia \\ rina_wulandari@uny.ac.id
}

\author{
Nur Hayati \\ Early Childhood Education Department \\ Faculty of Educational Science \\ Universitas Negeri Yogyakarta \\ Yogyakarta, Indonesia nurhayati@uny.ac.id \\ Arumi Savitri Fatimaningrum \\ Early Childhood Education Department \\ Faculty of Educational Science \\ Universitas Negeri Yogyakarta \\ Yogyakarta, Indonesia \\ arumi@uny.ac.id
}

\begin{abstract}
This research has the aim of developing a material guidance on parents gathering to improve the knowledge of children care among parents and teachers. Despite the themes in the material guidebook, there are fifteen titles available. This research is a developmental research using Borg and Gall model. The data collecting technique uses questionnaire with scale instrument. The technique of data analysis was done in a quantitative way. The result of the research shows that the development of the guidebook prototype of parents gathering is worthy to have a trial test in the field with some revisions. This could be seen from the judgment of material experts that show the score average of material validation as big as 63.4 or $64 \%$ (adequately worthy). Besides, the result of readability test by 42 teachers show the data that 3 teachers $(7,2 \%)$ stated that it is very good, 32 teachers $(76 \%)$ stated that it is good, and 7 teachers $(\mathbf{1 6 . 8 \%})$ sated that it is good enough. Next the scoring data from media validator gains the average score of $95,8 \%$ or $96 \%$ (worthy).
\end{abstract}

I.

Keywords- development, guidance, parents gathering, children care

\section{INTRODUCTION}

There are many factors that influence the conditions of Family is the smallest social unit in the society that has an important role in children education. If children have enrolled in an institution, the main persons who take the responsibility of the children's education are still their parents. Parents are considered the one who most understand the children's condition, with whom most children's time is spent at home with their family, especially the parents. This opinion is supported by Sunar who states that parents are figures who should for the most part know when and how their children could learn in the best way. The general Council of the United Nations [1] also asserts that the main function of a family is "as the place to educate, care, and socialize the children, develop the capability of all of its members in order that they are able to do their function well in the community, and give the sense of satisfaction, and a healthy environment in order to reach a wealthy family." In this matter, the parents "e role is deemed to give a greater contribution than other party does. There is no school to be parents, but at least parents could learn from the way their parents care and educate them. It is expected that they maintain the good values and discontinue the bad values. Aristotle gave a meaningful message about the role of parents, that is "we might not been able to prepare a future for our children but at least we could prepare them to face the future." Those meaningful statements should become the motivation for parents, to always improve their knowledge and do some reflection on their style in caring them these times that are surely giving influence to children's personality development.

Education in a family has a strategic value in giving examples and laying the important base through habituation. This is in line with Djamarah's opinion [2] that states that parents ${ }^{\text {ee }}$ model and habits are not separable from their children's attention and observation. The value taught by their parents will be obeyed by the children. Family education is very crucial to one's democratic attitude. The appreciation toward children as a human being that has their own view based on their experience, started from their parents or family member's appreciation [3]. They put to high expectation or the vice versa, too low expectation. Next, they do not be good listeners, they are not consistent in applying discipline, they let their children watch too much TV, they allow their children to eat too many sweets, and they are overprotective. All parents surely have good intentions for their children. 
However, the intention should also be accompanied by good ways. An example is the good intention to protect their children. Some parents are not aware if their good intention is sometimes in a way too much. It results in a big number of prohibition or limitation to the children. For sure too many prohibitions and being over protective in turn could make the children have low level of confidence and independence. Besides, loving children does not have to be accomplished by granting all that the children want and not letting the children to encounter any difficulty. Parents need to think wisely that difficulty and challenges would make the children to be great and ready in facing the future.

In the frame of making an effort on giving good and qualified nurture, The Education for Early Aged Children (PAUD), teachers, and parents need to make synergy, in order that the result of learning and the children's development could be optimum. Epstein [7] mentioned one form of synergy with parents is by making a parents ${ }^{\text {ee }}$ meeting, in which they are given education in order that their knowledge and skill in nurturing their children get better. If the parents ${ }^{e e}$ knowledge on the growth and development of their children is expected that getting better, then it be expected to, result in positive impact on their children parenting style.

In other words, parenting will be more qualified because the parents had gained adequate knowledge on children's development. Parenting is a process of raising and supporting the children's physic and mental development that include emotional, social, spiritual, and intellectual aspects from infant to adult [11] It is also interpreted as an educational effort done by the family by making use of all resources available in the family and environment [9].

Through the parents gathering it is expected that the parents are more able to understand the children's development, knowing about the suitable parenting style, being able to create home condition that is supportive to learning, and helping the teacher in gaining information about the children and at the same time improving the quality of parenting. In the activity of parents gathering, the institution of PAUD could invite an expert or resource that explains them about a trending topic or information needed by parents. The theme in a parents gathering should be adjusted with general problems that are usually experienced by parents and their children [10]. As the resource person, they could invite the parents to have a reflection in parenting like: the contribution of parents modeling to their children, the impact of prohibiting their children in a way to much, the harm of threatening their children frequently, managing the use of gadget in children, the way to motivate children, is my kids ready to join.

Based on observation in three kindergartens in Bantul. The data that some parents and teachers are still using threats in conditioning their children are found [11]. For example, if they do not finish their tasks then they will go home at the latest turn, if the children are stubborn or difficult to direct they will call their dads or police officers, and any other threats. Besides, some parents and teachers motivated the children by comparing them with other children, for example, they said "He could do it, why dont you? Come on do it. Be ashamed to your friends". These statements are for sure able to lower the children's selfesteem.

There were also some parents and teachers who gave advise or scolded their children in public so the children become very ashamed and lower their self-confidence. Sometimes, prohibitions are also given by some parents without giving any explanation or reason why it is prohibited. For examples they prohibited their children to buy some toys, they simply prohibited, scolded their children without giving an understanding why it is prohibited, and give an alternative activity or toys to the children.

Some parents and teachers also rarely give reinforcement or appreciations to the children. Some parents even in general give more emphasis on the children's negative behaviors. If the negative behavior that are not expected by the parents they will scold the children at once, but if the positive behaviors occur, some parents simply let it happen, they keep silent and they do not give any appreciation or reinforcement to the children.

The problem related to the development and behavior among the children often happen, but some teachers do not have any alternative to solve them. Some parents frequently have consultation with the teacher in relation to their children's behavior, but teachers are not able to take a deep look on the cause of the children's different behavior and they are not able to design alternative strategy to change the children's behavior yet either.

If the nurture given to the children is inappropriate, it is unexpectedly able to hinder and be disadvantageous to children's next development [12]. In responding to the problems that occur in the field and in considering the importance of the parenting quality, the researchers would like to design a prototype of parenting material guidebooks. These books contain interesting themes that are appropriate to the needs of the field.

They could be useful to improve the knowledge of the parents and the teachers about the children's growth and development, the parenting style and their impacts to the children's development. These guidebooks could be useful for the parents as a reading material to improve their knowledge, attitude, and skills, especially related to the nurture or parenting. Beside the teachers could also use the guidebooks as the material for parents gathering activity, in which the teacher could take the role as a resource person who accompanies the parents in optimize the development of their children before they come to the referral stage.

\section{METHODS}

The development of guidebooks prototypes is done based on the product developmental model of Borg \& Gall [1], but it is only done until number 5 that is revising the main product, as suitable with the advice from the early field test. The research is located in Sleman, Yogyakarta. The development procedure refers to the development by Borg and Gall [2] that involve the stages of preliminary study (literature study and need assessment), the stage of product development, instrument preparation stage, parents gathering guidebook prototype development stage, and 
expert examination stage (material, content, and readability test).

This research uses the data collecting technique in the form of questionnaires or scale, with the instrument of quantitative data in the form of scale [6]. The data analysis technique is done in descriptive quantitative way. The analysis result of expert examination is used as the basis to make a revision on the media in order that it is suitable for the early aged children development stage. The quantitative data gained through the scoring of the instrument by experts. The quantitative data is then conversed into qualitative data with the percentage formula to reveal the quality of the product.

\section{RESULT AND DISCUSSION}

\section{The result of Focus Group Discussion (FGD) with}

\section{Kindergarten Teachers}

This research consists of a number of activities series like doing literature study and the identification of the needs of developing parents gathering guidebook in Kindergarten. This research is done by exploratory literature by studying various theories of parents gathering. Besides, the researchers also do interviews with some teachers and principals of some kindergartens to know the administration of parents gathering that have been done in the kindergarten. Based on the interview, there is information that parents gatherings have been done in the kindergartens, using the term parenting ${ }^{\text {ee }}$.

Next from the interview it is also found information that there are some difficulties in the administration of parents gathering such as determining the suitable themes, difficulties in finding resource person, and difficulty in determining the time in order that most parents or even all parents could join in the activity of parents gathering. To answer the problem related to themes, the researcher tried to construct a prototype of guidebook of parents gathering to help the teachers and parents in improving the knowledge quality related to parenting, and at the same time to motivate the teachers to become a resource person or informant for the parents in the activity of parents gathering.

\section{The Themes Selected for the Parents Gathering Guidebook}

In this research, the materials are arranged based on the previous research that is a research by Muthmainnah that mentions themes of the problems of social emotional of the children in related to the education. The themes are: getting used to lie in front of the children, frequently threatening the children, prohibiting the children too much, father and mother are not unified in taking care of their children, not consistent in applying discipline, motivating children by comparing them with other children, and being overprotective to children. From the result of the previous research, the researcher then gives additional themes based on the observation in related to the needs and problems experienced by most kindergarten children, and having a focused group discussion with teachers.
Whereas the material developed in the parents gathering guidebook are: the chicken will die if you do not eaten up the meal, getting used to lie to the children, frequently threatening the children, having too many prohibitions, father and mother are not unified in taking care of the children, being not consistent in applying discipline, motivating by comparing their children with others, often blaming the children, scolding children in public, giving a too high expectation or the vice versa, too low expectation, being over protective to the children, my kids are able to sing adult songs-and they do it while dancing too, when our kids are bullied by their peers, managing the use of gadget for children, and is my kid ready to join elementary school.

The fifteen materials are arranged in three subjects that include preface, the following impacts, and alternative solutions that could be done by the parents and teachers in handling the children's problems. The materials try to relate between phenomena and relevant theory in order to strengthen the treatment or actions that could be done by the parents as solution for the problem. Besides, the materials are arranged in simple statements in order that they are easily understood by the readers, especially the teachers and parents. In order to result in a worthy parents gathering guidebook, the researcher use expert tests on(material and media) and a readability test from kindergarten teacher.

\section{The Result of Material Validation Test}

The guidebook for parent gathering material compiled by the research team as many as fifteen materials are then tested by some validator, one of them is the material (content) expert. In this research, the researchers invite the material validator. Based on the judgment of the material (content) validator, the prototype of parents gathering guidebook needs some revision. The scoring data from the validator is from the writing structure that include grammar, vocabulary, and sentence structure, it gains score 3 (Good), from the readability side that include the use of sentences that are easily understood, it gains score 4 (very good); the completeness and the orderliness it gains score 2 (enough). Next from the content of the guidebook that includes the preface, relating the relevant theory, contains the solution or alternative solution gains score 2 (enough). In details, the result of scoring of the validation of the material is seen in Table 1.

Table 1 it is obvious that the material validator give average score $63.8 \%$ or $64 \%$. This shows that the guidebook is quite worthy and it still needs to be revised before the field test. The validator also gives written advice that is related to the writing format that should be completed, the material structure that should be uniformed, the reference updating, the detailed solution, and in order that it is more directed to parents. Based on the advice from the material (content) validator, the researcher team makes some revision to complete the prototype of parents gathering guidebook. 
Table 1. The Result of Material Validation

\begin{tabular}{|c|c|c|c|c|c|c|}
\hline No & Component & $\begin{array}{l}\text { Scoring } \\
\text { Descriptors }\end{array}$ & 12 & & 3 & 4 \\
\hline \multirow[t]{3}{*}{1} & \multirow[t]{3}{*}{$\begin{array}{l}\text { Writing } \\
\text { Order }\end{array}$} & $\begin{array}{l}\text { a. The grammar is } \\
\text { suitable with the Ejaan } \\
\text { Yang Disempurnakan }\end{array}$ & & & $\mathrm{V}$ & \\
\hline & & $\begin{array}{l}\text { b. The vocabulary } \\
\text { is easy to understand }\end{array}$ & & & $\mathrm{V}$ & \\
\hline & & $\begin{array}{l}\text { c. The sentence } \\
\text { structure is complete and } \\
\text { accurate }\end{array}$ & & & $\mathrm{V}$ & \\
\hline \multirow[t]{3}{*}{2} & \multirow[t]{3}{*}{ Readabi-lity } & $\begin{array}{l}\text { d. The sentences } \\
\text { are easily understood }\end{array}$ & & & & $\mathrm{V}$ \\
\hline & & $\begin{array}{l}\text { e. The } \\
\text { completeness } \\
\text { of the material } \\
\text { given }\end{array}$ & $\mathrm{v}$ & & & \\
\hline & & f. Orderliness & $\mathrm{v}$ & & & \\
\hline \multirow[t]{3}{*}{3} & \multirow[t]{3}{*}{$\begin{array}{l}\text { The content } \\
\text { of the } \\
\text { guidebook }\end{array}$} & $\begin{array}{l}\text { g. It contains } \\
\text { relevant preface }\end{array}$ & $\mathrm{v}$ & & & \\
\hline & & $\begin{array}{l}\text { h. It relates } \\
\text { relevant theory }\end{array}$ & $\mathrm{v}$ & & & \\
\hline & & $\begin{array}{l}\text { i. It contains } \\
\text { solutions or alternative } \\
\text { resolutions on } \\
\text { relevant } \\
\text { parenting problem }\end{array}$ & $\mathrm{v}$ & & & \\
\hline
\end{tabular}

$0 \%-25 \%=$ not worthy Notification:

$26 \%-50 \%=$ less worthy

$51 \%-75 \%=$ worthy enough

$76 \%-100 \%=$ worthyon

The media test is conducted by seeking for scoring from media validator. The scoring is viewed from the technical side that include design/lay out, durability, and safety. Besides, from the aesthetic side, it includes the suitability of the book size, the pictures attraction, and color attraction score 4 is gained. Whereas, the indicators of the suitability of the size gains score 3 . In detail, the result of the media validation could be seen in Table 2

Table 2. The Result of Media Validation Scoring

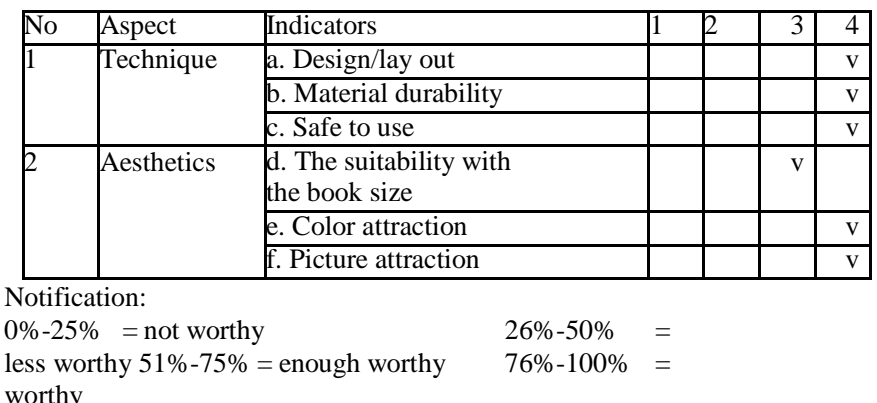

Based on Table 2 it could be seen that the media validator give the average score of $95,8 \%$ or $96 \%$ (worthy). This shows that the guidebook is worthy to be tried in field.The Result of Readability Test of The Guidebook by the Teachers.

The teachers are also invited to help the researchers to do a readability test of the prototype of the guidebook for parents gathering. The researchers involve 42 kindergarten teachers to study the parents gathering guidebook either from the writing or in terms of the content. From the side of the writing structure, the researcher try to improve based on the notes given by the teachers in the sheets of material guidebook.

Then the 42 teachers are also asked to give the quantitative score toward content by giving score 1-4 to the 15 indicators in the scoring scale of parents gathering material. Whereas the 15 indicators include the content and the aspect of media that the components are the same as those scored by the validator. There are 15 indicators scored by the teachers, where 1 indicator is scored as lack, score 2 means enough, score 3 means good, and score 4 is interpreted as very good.

Tabel 2. Quantitative Score

\begin{tabular}{|l|c|c|}
\hline No & Score & Number \\
\hline 1 & Very good & 3 \\
\hline 2 & Good & 32 \\
\hline 3 & Enough & 7 \\
\hline
\end{tabular}

Quantitatively, the gained result that 3 teachers $(7.2 \%)$ score very good, 32 teachers $(76 \%)$ score good, and 7 teachers $(16.8 \%)$ give scores good enough to the parents gathering guidebook and the result of readability test of the guidebook is described in Fig. 1.

Next if it is seen from the average score between indicators of readability test it is gained data that the indicator that gain the lowest average is the color attraction of 2.3, while the indicator of the thought orderliness is 3 , the indicator of design is 3 , the indicator of vocabulary that is easy to understand is 3.07 , the indicator of the sentence that is easily understand is 3.11 , indicator of relating to the relevant theory is 3.14 , and the indicator of media safety is 3.2. The gained result of the average of all indicators in the readability test is $\geq 3$ could be described in Fig. 2

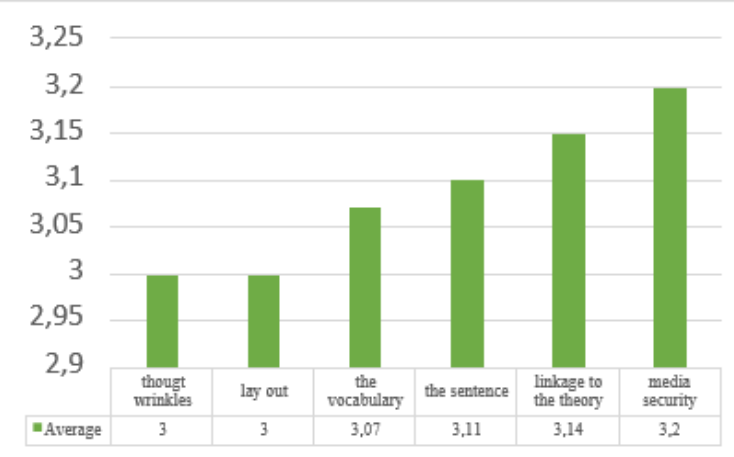

Fig. 1. The Number of Indicator for Gain Scores

Based on Fig. 1. it could be seen that the number of indicators that gain score 3 or more is 6 . Besides the indicator that has the highest score in the readability test is the media safety, it means that the guidebook media is considered safe by the teachers. Educating and raising children in order to be useful humans are the parentse responsibility. This is supported by Ki Hajar Dewantara ${ }^{\text {ee }} \mathrm{s}$ statement that states that the essential of education is the responsibility of the family, while school is only taking part [14]. However, some parents have not been able to 
understand their children, and there are children who do not understand their parents either. As a result, the relationship between children and their parents become tenuous [7]. Some parents also use their prerogative right, where children must obey them and must not fight their parents, so the children are getting far from their parents. Trust is an essential element, so the direction, guidance, and assistance given by parents will be ,united ${ }^{\text {ee }}$ and children will easily catch the meaning [14].

In the parenting by parents at home, some problems related to the mal-nurturing frequently happen. Based on early interviews done by the researchers, it is found information that some parents generally continue the parenting style of their parents without reflecting whether the parenting style they did gave in accordance with an opinion by Shonkoff [13] that reveals the mistakes of some parents, namely: first, they are frequently impatient in facing the children. They put a too high expectation or the vice versa, too low expectation. Next, they do not be good listeners, they are not consistent in applying discipline, they let their children watch too much TV, they allow their children to eat too many sweets, and they are overprotective.

The results show that children whose parents take care of hard and full of anger tend to develop behavioral styles, emotional regulation strategies, and cognition that result in poor adjustments in children, and children tend to feel ashamed if parents underestimate and criticize their behavior [3]. Istadi [8] asserts that parents need to make their children special; it means that parents must be patient in facing children, believe in their children's capability, and be able to appreciate their children's uniqueness. In the frame of improving the parenting quality, some efforts need to be done; one of them is parents gathering.

This statement is supported by Epstein [7] who states that one form of synergy with parents is parents gathering, where in the meeting they could be given education in order that their knowledge and skill related to their children's growth and development are getting better. If the parentse knowledge about the growth and development of their children are getting better, therefore it is expected that it could give a positive impact in their parenting style to their children.

In general, people know more about the term parenting than parents gathering do. Parenting is also interpreted as the effort of educating done by a family by utilizing the resources that are available in the family and environment. Through the parents gathering it is expected that the parents are more able to understand the children's development, knowing about the suitable parenting style, being able to create home condition that is supportive to learning, and helping the teacher in gaining information about the children and at the same time improving the quality of parenting. In the bio-ecological approach, early childhood classes have an important role, in which children can develop social and emotional abilities [4]. Meanwhile, parents are invited to school to hear the explanation fromthe presenter related to the problems of children's problems and the alternative ways to handle.
In this research, fifteen materials are arranged in relation to parents gathering, they are: the chicken will die if you do not eaten up the meal, getting used to lie to the children, frequently threatening the children, having too many prohibitions, father and mother are not unified in taking care of the children, being not consistent in applying discipline, motivating by comparing their children with others, often blaming the children, scolding children in public, giving a too high expectation or the vice versa, too low expectation, being over protective to the children, my kids are able to sing adult songs-and they do it while dancing too, when our kids are bullied by their peers, managing the use of gadget for children, and is my kid ready to join elementary School?

The fifteen materials are considered relevant and good by 42 teachers who are asked to give score on readability test. This statement is supported by the data namely 1 teacher give a very good score, 31 give good score, and 10 teacher give enough score. This is a little bit different from the advice of the validator of material or content who give scores on the indicator of material completeness, the orderliness, the containing of preface, related to the relevant theories, and having solution or solution alternative that gains score 2 (enough).

In the frame of providing good and qualified parenting, then in the institution of Early Aged Children Education (PAUD), teachers and parents need to have good synergy, in order that the learning result and the development of the children become optimum. By means of the research product in the form of fifteen parents gathering material guidebook, it is expected that the guidebook could be useful for the teachers and improve the knowledge and awareness of the parents in relation to the quality of parenting and education of their children so their growth and development are getting optimum.

The development of parents gathering guidebook is stated to be worthy so it could be continued to have a further trial test on the field. This could be seen from the instrument testing from material expert. The scoring data from the material validator are: from the aspect of writing structure that include grammar, vocabulary, and sentence structure it gets score 3 (god), from the aspect of readability that include the use of sentences it gets score 4 (very good), from the aspect the completeness and the orderliness of the material, it get score 2 (enough), and from the aspect of the content of the guide book that include the preface, related to relevant theory, and it contains the solution or alternative solution, it gains score 2 (enough). Therefore, the average of material validation is 63,8 , or $64 \%$ (worthy enough). In addition, the result of the readability test of the guidebook by 42 teachers shows the data that 3 teachers $(7.2 \%)$ give a very good score, 32 teachers $(76 \%)$ give good score, and 7 teachers $(16.8 \%)$ give good enough scores toward the material of parents gathering guidebook. Next the data from media validator, that is from the indicators of design/lay out, the material durability, the media safety, and the picture attractiveness and color attractiveness it gains score 4 , while the indicator of the suitability with the book size it ganis score 3 , or in the other words it ganis the average score of $95,8 \%$ or $96 \%$ (worthy). 


\section{REFERENCES}

[1] Prasetyono, D S. Membedah psikologi bermain anak. Yogyakarta: Penerbit Think, 2007.

[2] Bronfenbrenner, U. Ecology of the family as a context for human development: Research perspectives. Developmental Psychology 22(6), 723-741. 1986.

[3] Sochib, M. Pola asuh orang tua dalam membantu anak mengembangkan disiplin diri. Jakarta: Rineka Cipta, 2000

[4] Ratnawati, S dkk. Keluarga kunci sukses anak. Jakarta: PT Kompas Media Nusantara, 2001.

[5] Arikunto, S. Prosedur penelitian. Jakarta: PT Rineka Cipta, 2006.

[6] Borg, W.R \& Gall, M.D. Educational research an introduction. fourth edition. New York: Longman Inc, 1983.

[7] Brody, G. H., Flor, D., \& Gibson, N. M. Linking maternal efficacy beliefs, developmental goals, parenting practices, and child competence in rural single parent African American families. Child Development, 70(5), 1197-1208.1999.
[8] Coleman, M. Empowering family-teacher partnership building connections within diverse communities. Los Angeles: Sage Publication: 2013.

[9] Djamarah, S B. Pola komunikasi orang tua dan anak dalam keluarga Jakarta: PT Rineka Cipta, 2004.

[10] Edwards, C D. Ketika anak sulit diatur. Panduan bagi orang tua untuk mengubah perilaku anak. Bandung: Kaifa, 2006.

[11] Megawangi, R. Pendidikan karakter untuk membangun masyarakat madani. IPPK Indonesia Heritage Foundation, 2003

[12] Parents guide. Pengertian parenting dan gaya pengasuhan. Diakses dari www.parents.co.id padatanggal 25 Januari 2017.

[13] Severe, S. Bagaimana bersikap pada anak agar anak prasekolah bersikap baik. Gramedia Pustaka Utama: Jakarta, 2003.

[14] Wright, N. Menjadi orang tua yang bijaksana. Andi Offset: Yogyakarta, 2009. 